\title{
Geochemistry of Sodium Alkaline Igneous Formations in NE Vietnam: Evidence of Paleohotspot \& Mesohotspot Traces
}

\author{
Nguyen Trung Chi ${ }^{1}$, Martin F. J. Flower ${ }^{2}$ \\ ${ }^{1}$ Petroleum Department, Petrovietnam University (PVU), Ba Ria City, Ba Ria- Vung Tau Province 74000, Viet Nam \\ ${ }^{2}$ Department of Earth and Environmental Sciences, University of Illinois-Chicago, (UIC), USA
}

Email address:

chint@pvu.edu.vn (N. T. Chi), flower@uic.edu (M. F. J. Flower)

\section{To cite this article:}

Nguyen Trung Chi, Martin F. J. Flower. Geochemistry of Sodium Alkaline Igneous Formations in NE Vietnam: Evidence of Paleohotspot \& Mesohotspot Traces. Science Research. Vol. 3, No. 2, 2015, pp. 38-44. doi: 10.11648/j.sr.20150302.12

\begin{abstract}
Researched results on geochemistry of major, trace and isotopic elements from igneous formations in NE Vietnam area have established a Sodium alkaline igneous Province (Chi Nguyen et al., 2004), which consist of a chain of alkaline igneous formations: ijolite- melteigite- jacupirangite- nepheline syenite rocks from Pia Ma massif (Tuyen Quang) toward SE distance $\sim 200 \mathrm{~km}$ via Bang Phuc massif (Bac Kan), and then to Ngoi Biec one (Yen Bai) towards SW $250 \mathrm{~km}$, they created a assemblage of alkaline ultramafic-mafic and nepheline syenite rocks at Viet Bac Craton, that is a part of South China Platform margin. The research on petrogenesis of the above mentioned alkaline rocks show that: 1) Alkaline ultramafic - mafic rocks and nepheline syenite has a very high content of $\left(\mathrm{Na}_{2} \mathrm{O}+\mathrm{K}_{2} \mathrm{O}\right)$ from (1.94-8.4\%) to (9.62-16.7\%), high $\mathrm{Al}_{2} \mathrm{O}_{3}$ from (6.88$16.93 \%)$ to $(17.2-24.32 \%)$ belong to both alkaline ultramafic- mafic groups and nepheline syenite rock. The $\mathrm{P}_{2} \mathrm{O}_{5}$ content of those 2 groups is very high (0.7-1.10\%). Agpait Index (AI) of nepheline syenite rocks $<1$, but $\mathrm{Na}>\mathrm{K}$ and $\mathrm{Ca}, \mathrm{Mg}$ contents is high, showing nepheline syenite is the miaskitic type. The total content of (REE+Y) varies from $164 \div 432 \mathrm{ppm}$ with $\mathrm{Ce} / \mathrm{Y}=2.83 \div 6.64,(\mathrm{La} / \mathrm{Sm})_{\mathrm{N}}=4.12,(\mathrm{Ce} / \mathrm{Sm})_{\mathrm{N}}=2.64,(\mathrm{Yb} / \mathrm{Lu})_{\mathrm{N}}=1.27, \mathrm{Eu} / \mathrm{Eu}^{*}=0.1-0.28$. However, the range isotope content of $\mathrm{Sr}$ and $\mathrm{Nd}$ in whole rocks of Pia Ma and that of Cho Don are different, in Pia Ma: $0.705846 \div 0.706419$ and $0.511831 \div 0.511975$ with value of $\varepsilon_{\mathrm{Nd}}=-2.35 \div+0.12$ belong to EM1- type and aged in $519 \pm 40 \mathrm{Ma}$ (Early Cambrian); in Cho Don: $0.709893 \div$ 0.718356 and $0.511854 \div 0.512010$ with value of $\varepsilon_{\mathrm{Nd}}=-9.79$ to -2.9 belong to EM2-type and aged in $231 \pm 23 \mathrm{Ma}$ (Late Triassic ). 2) The geochemical characteristics of trace elements and isotope from above rocks indicated that, have fractional crystallization of a mixed magma liquid with composition of nephelinite derived from partial melting of depleted mantle source. This magma source may intruded into crust at Pia Ma in Early Paleozoic (Paleohotspot trace) and then at Cho Don and Ngoi Biec in Late Triassic (Mesohotspot traces) as they pass over "hotspot" in mantle. Possibly, this hotspot reactivated in Eocen and by the way to open the East Sea. The movenment speed of South China Plate towards North is about 0,7- 2,2 $\mathrm{mm} / \mathrm{year}$.
\end{abstract}

Keywords: Sodium Alkaline Igneous, Ijolite-Melteigite-Jacupirangite, Nepheline Syenite, Hotspot Traces

\section{Introduction}

Sodium alkaline Igneous Rocks are a few dissemination in Earth's crust but It is sourse providing many category of mineral resources shuch as REE, U,Th, Ta, Nb... and other rare alkaline metals as $\mathrm{Rs}, \mathrm{Cs}, \mathrm{Li}$...

Sodium alkaline igneous formations in NE Vietnam ( Fig. 1) were discovered by Chi Nguyen et al., 2004 consist of a chain of alkaline igneous formations: ijolite- melteigite- jacupirangite- nepheline syenite rocks from Pia Ma massif (Tuyen Quang) toward SE distance $\sim 200 \mathrm{~km}$ via Bang Phuc massif (Bac Kan), and then to Ngoi Biec one (Yen Bai) towards $\mathrm{SW} \sim 250 \mathrm{~km}$, they created a assemblage of alkaline ultramafic-mafic and nepheline syenite rocks at Viet Bac Craton, that is a part of South China Platform margin. 


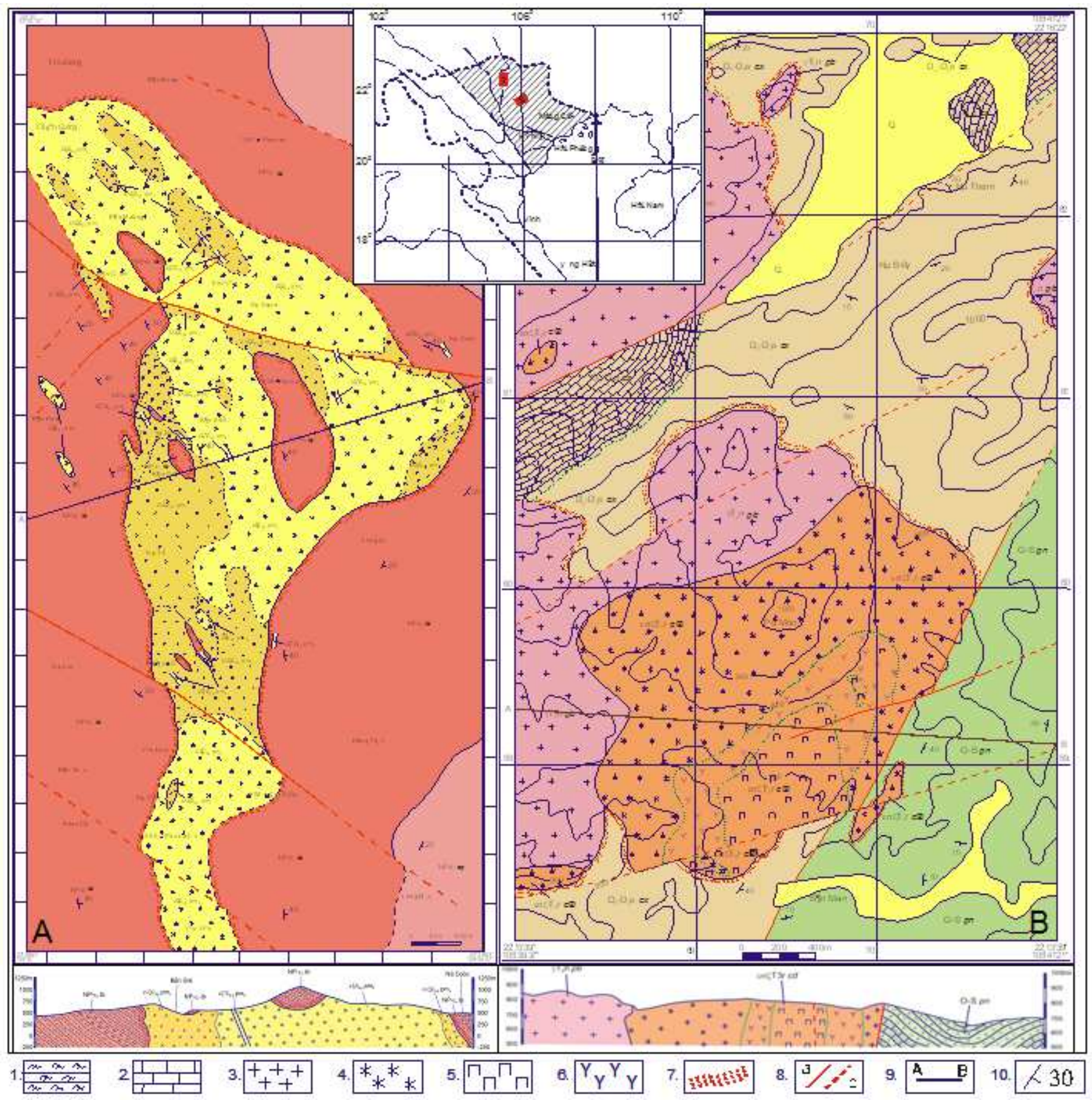

Fig. 1. Geological Sketchmap of Pia Ma Masif (A) Bang Phuc (B) and position of the in NE Vietnam Area.

1. Two mica quartzt schist; 2. White limestone; 3. Biotite granite; 4. Alkalic syenite, nepheline syenite; 5. Ijolite; 6. Melteigite; 7. Geological boundaries, 8. Faullts.

\section{Characteristics of Geology and Mineral - Petrographic Features}

In Cho Don localities (Bac Kan Province) and Ngoi Biec (Yen Bai Prov.), alkaline ultramafic-mafic formations include jacupirangite and ijolite series (ijolite, urtite, melteigite), and alkaline gabbroids transition via nepheline syenite - alkalic syenite and latest member is sodalite - bearing pegmatites of nepheline syenite cutting above mentioned rocks. While, in Pia Ma (Tuyen Quang Prov.) alkaline ultramafic-mafic formation discovered under the forms of xenoliths have composition of garnete- nepheline -hornblendite inside nepheline syenites, and smaller bodies have composition of ijolite - melteigite, alkalic gabbroic dykes - theralites.

Major mineral composition consist of K-feldspar (50$75 \%$ ); albite (1- 18\%); nepheline (5-30\%) sometimes was changed by cancrinite; biotite (0- $2 \%)$. Accessories: apatite, calcite. Secondary minerals: cancrinite, sodalite $(0,5 \%)$, little of muscovite, epidote. In nepheline syenite there is some of hastingsite, arfvedsonite, aegirine - augite (Fig. 2). 


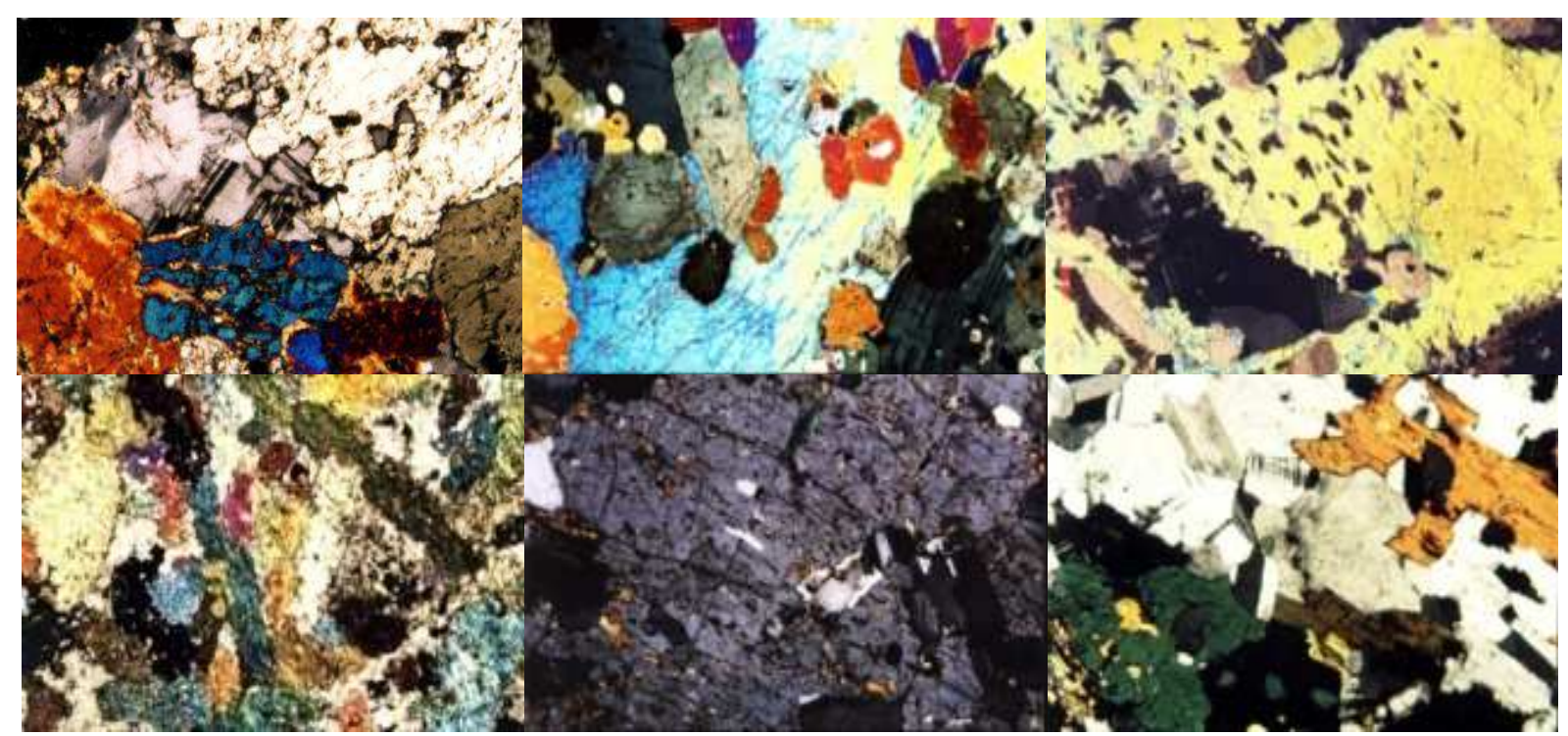

2a. Jacupirangite, 2b. Ijolite, 2c. Urtite, 2d. Melteigite, 2e. Nepheline syenite, 2f. Alkaline syenite.

Fig. 2(a,b,c,d,e,f). Petrographical composition of alkaline ultramafic- mafic association and nepheline syenit in NE Vietnam Area.

\section{Geochemistry of Major Elements}

Nepheline syenite at Bang Phuc and Ngoi Biec Massifs have high alkalic total: $\left(\Sigma \mathrm{Na}_{2} \mathrm{O}+\mathrm{K}_{2} \mathrm{O}=13,52-16,95 \%\right)$ and alkaline ultramafic -mafic rocks there are low alkalic total : $\left(\Sigma \mathrm{Na}_{2} \mathrm{O}+\mathrm{K}_{2} \mathrm{O}=1,62-8,69 \%\right)$. At Pia Ma massif: $\Sigma \mathrm{Na}_{2} \mathrm{O}+\mathrm{K}_{2} \mathrm{O}$ $=9,62-14,23 \%$ (in nepheline syenite) and $=\Sigma \mathrm{Na}_{2} \mathrm{O}+\mathrm{K}_{2} \mathrm{O}=$ $2,15-5,84 \%$ (alkaline ultramafic - mafic rocks) (Fig.2). In nepheline syenite and alkalic ultramafic - mafic, Sodium content higher Potassium $\left(\mathrm{Na}_{2} \mathrm{O} / \mathrm{K}_{2} \mathrm{O}>1\right)$, Generally, alkaline ultramafic-mafic - nepheline syenite in NE Vietnam Area be long to type of sodium alkali (Fig. 3). Nepheline syenite and alkalic syenite there is Aluminum content very high $\left(\mathrm{Al}_{2} \mathrm{O}_{3}=\right.$ $20,44-24,34 \%)$ in Bang Phuc massif and $=(17,16-22,98 \%)$ in Pia $\mathrm{Ma}$, while in alkaline ultramafic-mafic there is $\mathrm{Al}$ content of $\mathrm{Al}_{2} \mathrm{O}_{3}=(10,13-24,11 \%)$ in Bang Phuc and $=(6,88-$ $16,88 \%$ ) in Pia Ma. $\sum \mathrm{CaO}+\mathrm{Fe}_{2} \mathrm{O}_{3}$ and $\sum \mathrm{MgO}+\mathrm{FeO}$ in alkaline ultramafic -mafic rocks always also higher than nepheline syenite and alkalic syenite of the same differentiated series (Nockolds, 1954).

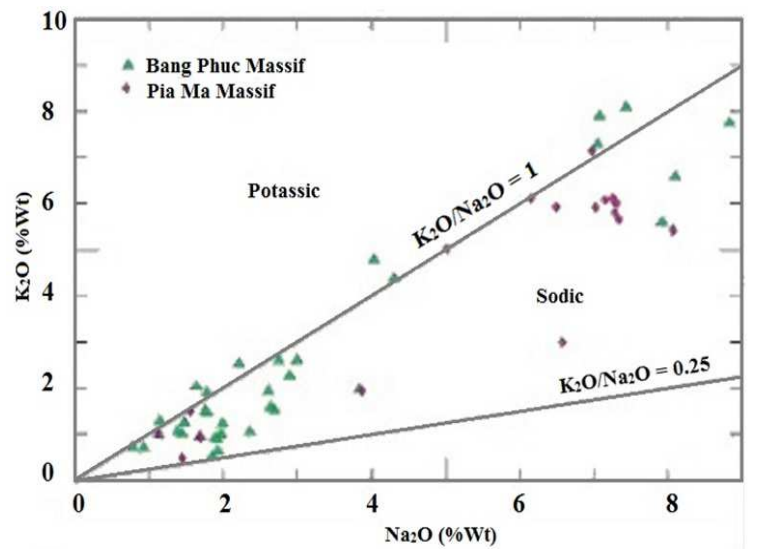

Fig. 3. Sodium and Potassium type of NE Vietnam Igneous Rocks.
Because of alkalic Index $-\mathrm{AI}<<1$ ought to nepheline syenite at Bang Phuc, Ngoi Biec and Pia Ma all belong to Miaskitic type. Aluminum Index very high $-\mathrm{A} / \mathrm{NK}>>1$; and Shand Index- A/CNK $<1$,

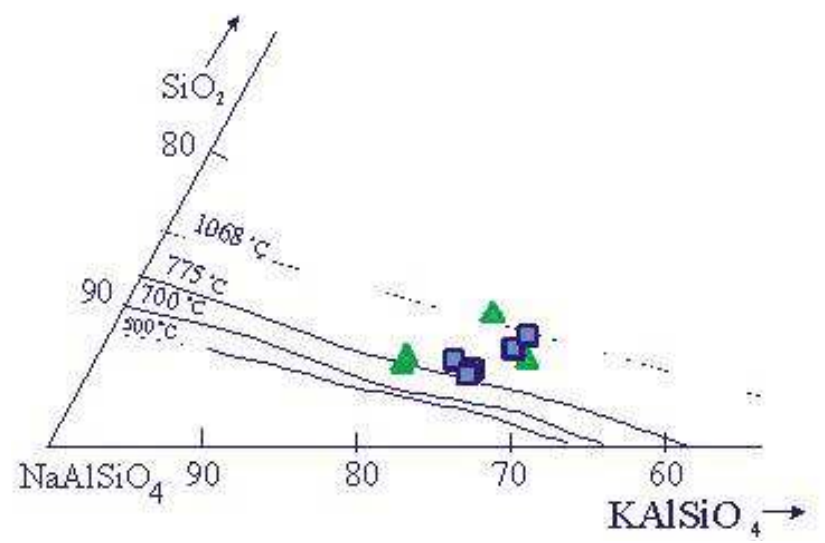

Fig. 4. Crystalized condition of nephelines in NE Vietnam Igneous Rocks on $Q-\mathrm{Ne}-\mathrm{K}$ diagram.

Especially lower in alkaline ultramafic-mafic rocks (overage content $<0,5$ ), this shown alkaline magmatic liquids derived from upper mantle and mixed with crust (Bergman, 1987).

\section{Geochemistry of Trace Elements}

Concentration of mobile elements as $\mathrm{K}, \mathrm{Rb}, \mathrm{Sr}, \mathrm{Th}, \mathrm{Ba}$ of nepheline syenite and alkalic ultramafic-mafic rocks varied in a wide range in Cho Don and Ngoi Biec but not change in $\mathrm{Pia} \mathrm{Ma}$. Concentration of $\mathrm{Ba}$ and $\mathrm{Sr}$ of nephelin syenite increase higher than alkalic ultramafic-mafic rocks in both Cho Don and Pia Ma. Its show that contamination of crusted materials increasing during intrusion of initial melting liquids 
into crust.

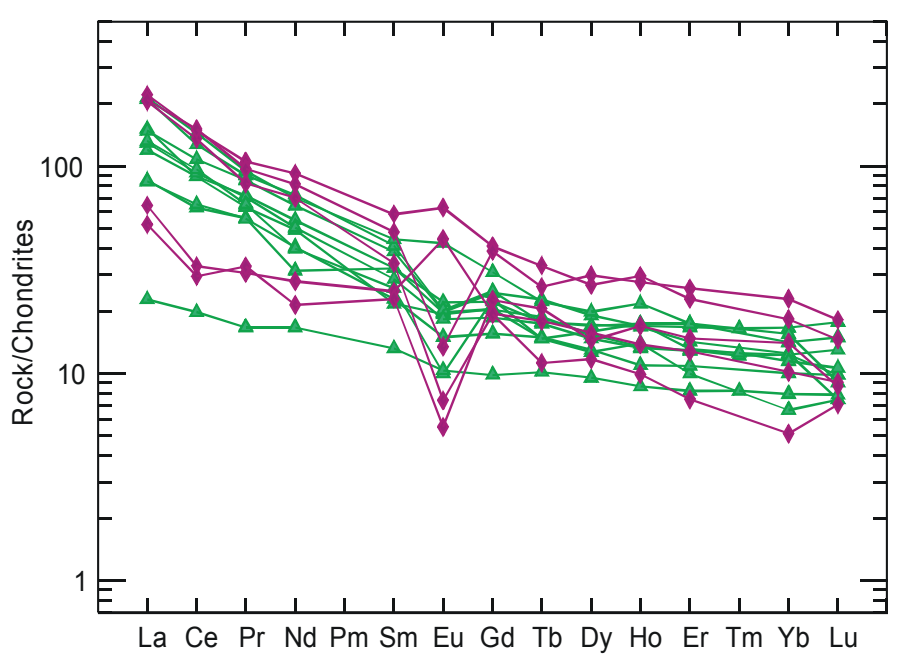

(a)

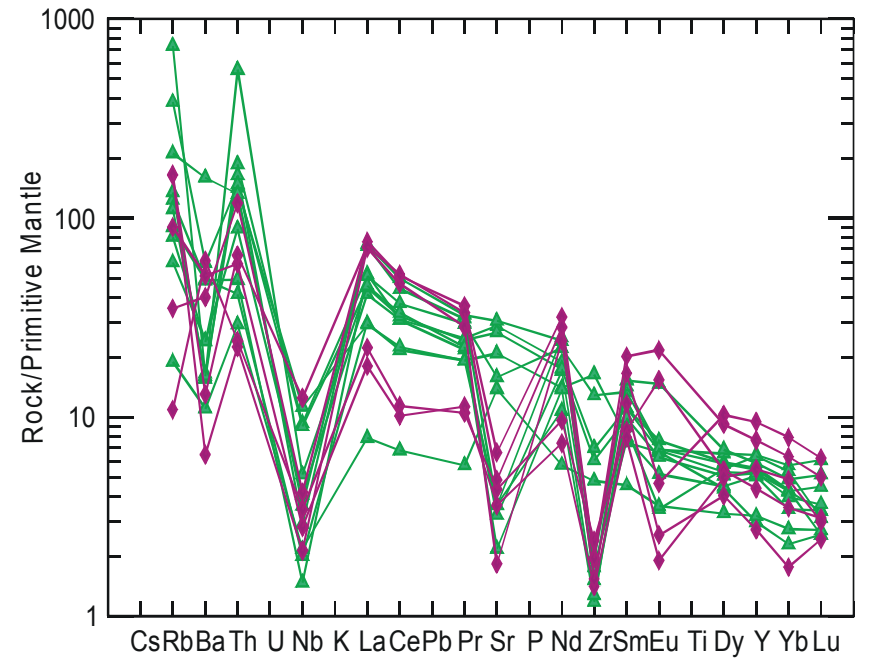

(b)

Fig. 5. (a) Chondrite-normalized REE distribution and (b) Primitive Mantle-Normalized Trace Elements distribution for Sodium alkaline Igneous Rocks in NE Vietnam.

Immobile elements with average ratios of $\mathrm{Nb} / \mathrm{Ta}=14,48$ from Bang Phuc's sodium alkalic rocks higher than Pia Ma $(\mathrm{Nb} / \mathrm{Ta}=12,25)$; and average ratios of $\mathrm{Zr} / \mathrm{Hf}=46,97-64,72$ in Pia Ma massif and $\mathrm{Zr} / \mathrm{Hf}=61,58-51,67$ in Bang Phuc massif . After V. I. Gerasimovsky (1968), above ratios of $\mathrm{Nb} / \mathrm{Ta}$ và $\mathrm{Zr} / \mathrm{Hf}$ of sodium alkalic formations in NE Vietnam are typical character of alkaline igneous by early magmas stage in Pia Ma and late stage in Bang Phuc. Appearance of sodalit in foid pegmatite of Bang Phuc massif shown that melting liquids of late stage is fluid - rich of alkalic metal and $\mathrm{Cl}, \mathrm{F}, \mathrm{CO}_{2}$

Concentration of REE and $\mathrm{Y}$ of sodium alkalic rocks in NE Vietnam varieties in wide interval; In both alkaline ultramafic-mafic rocks and alkaic syenitoid of Pia Ma and Bang Phuc, ratios of $\mathrm{Eu}^{\mathrm{n}} / \mathrm{Eu}^{*}<1$ Fig.5a). On PMNormalized diagram of trace elements of sodium alkaline rocks in NE Vietnam(Fig.5b) show that, they were derived the same a upper mantle source. Crystalized condition of nepheline $(\mathrm{Ne})$ on diagram of $\mathrm{SiO}_{2}-\mathrm{NaAlSiO}_{4}-\mathrm{KAlSiO}_{4}$ (Q-Ne-K) (MacKenzie, 1975) shown that sodium alkaline rocks crystalized with $\mathrm{T}=750-1000^{\circ} \mathrm{C}$ and $\mathrm{P}=1-5 \mathrm{kbar}$ (Fig.4).

\section{Origin of Sodium Alkaline Igneous in NE Vietnam}

\subsection{Characteristics of Isotope Elements and Age of Sodium Alkalic Igneous in NE Vietnam}

Isotope analyse of $\mathrm{Rb}-\mathrm{Sr}, \mathrm{Sm}-\mathrm{Nd}$ and radioactive age from whole rocks of Pia Ma massif's nepheline syenite and Ijolite (Fig.6a \& Fig.7a) show that ratio of ${ }^{87} \mathrm{Sr} /{ }^{86} \mathrm{Sr}$ (i) $=$ 0,706150 and ${ }^{143} \mathrm{Nd} /{ }^{144} \mathrm{Nd}(\mathrm{i})=0,511890$ with $\varepsilon_{\mathrm{Nd}(\mathrm{i})}=-2,35 \div$
$+0,12$ and Age $=519 \pm 40 \mathrm{Ma}$, approximate age of CHUR $=$ $697 \pm 3,5 \mathrm{Ma}$ With ratio of ${ }^{147} \mathrm{Sm} /{ }^{144} \mathrm{Nd}($ CHUR $)=0,125795$; $\varepsilon_{\mathrm{Nd}}($ CHUR $)=+5,13$ and ${ }^{87} \mathrm{Sr}{ }^{86} \mathrm{Sr}_{(0)}=0,708197 \div 0,711950$ and ratio of ${ }^{143} \mathrm{Nd} /{ }^{144} \mathrm{Nd}{ }_{(0)}=0,512288 \div 0,512376 ; \varepsilon_{\mathrm{Nd}(0)}=$ $6,87 \div-5,11$ Its proved that melting liquids derived enriched mantle source $-\mathrm{EM}_{1}$.

Isotope analyse of $\mathrm{Rb}-\mathrm{Sr}, \mathrm{Sm}-\mathrm{Nd}$ and radioactive age from whole rocks of Bang Phuc massif's nepheline syenite and Ijolite (Fig.6b \& Fig.7b) show that ratio of ${ }^{87} \mathrm{Sr} /{ }^{86} \mathrm{Sr}(0)=$ $0,709521 \div 0,709856$ and ${ }^{143} \mathrm{Nd} /{ }^{144} \mathrm{Nd}_{(0)}=0,512047 \div$ 0,512049 with $\varepsilon_{\mathrm{Nd}(0)}=-11,53 \div-11,51$ with Age $=220 \pm 1$ Ma, far diferent age of CHUR $=1437 \div 1182 \pm 3,5$ Ma With ratio of ${ }^{147} \mathrm{Sm} /{ }^{144} \mathrm{Nd}(\mathrm{CHUR})=0,127619$ and $\varepsilon \mathrm{Nd}(\mathrm{CHUR})=$ $3,71 \div+4,30$ and also far different age of deplepted mantle with $\left(\mathrm{T}_{\mathrm{DM}}\right)=1896 \div 1620 \mathrm{Ma}$. Its proved that this nephelin syenit derived enriched mantle source - $\mathrm{EM}_{1}$. For Bang Phuc massif's Ijolite rocks is ratio of ${ }^{87} \mathrm{Sr} /{ }^{86} \mathrm{Sr}{ }_{(0)}=0,709693$ and ratio of ${ }^{143} \mathrm{Nd} /{ }^{144} \mathrm{Nd}{ }_{(0)}=0,512144$ with $\varepsilon_{\mathrm{Nd}}=-9,7$ have age of $231 \pm 2 \mathrm{Ma}$ also far different age of CHUR $=724 \mathrm{Ma}$ with ratio ${ }^{147} \mathrm{Sm} /{ }^{144} \mathrm{Nd}_{(\mathrm{CHUR})}=0,093004$ and $\varepsilon_{\mathrm{Nd}}(\mathrm{CHUR})=5,43$; $\left(\mathrm{T}_{\mathrm{DM}}\right)=1130 \mathrm{Ma}$.

Thus, age of CHUR of Bang Phuc massif's ijolite and of Pia Ma massif's nepheline syenite is approximate each other and close to age of $\mathrm{EM}_{1}$ of Pia Ma's nepheline syenite about $(519 \pm 40 \mathrm{Ma})$. Its proved initial source of alkaline ultramafic liquids when intruded into crust at Pia Ma locality about 520 Ma prior, and then continued reactive and intruded into crust after about $250 \div 270 \mathrm{Ma}$ at Cho Don and Ngoi Biec with crystallised age of about $220 \div 230 \mathrm{Ma}$. This is only able to occurred inner stable craton (that period the NE Vietnam belong to marginal part of South China Craton with namely Viet Bac Craton). 

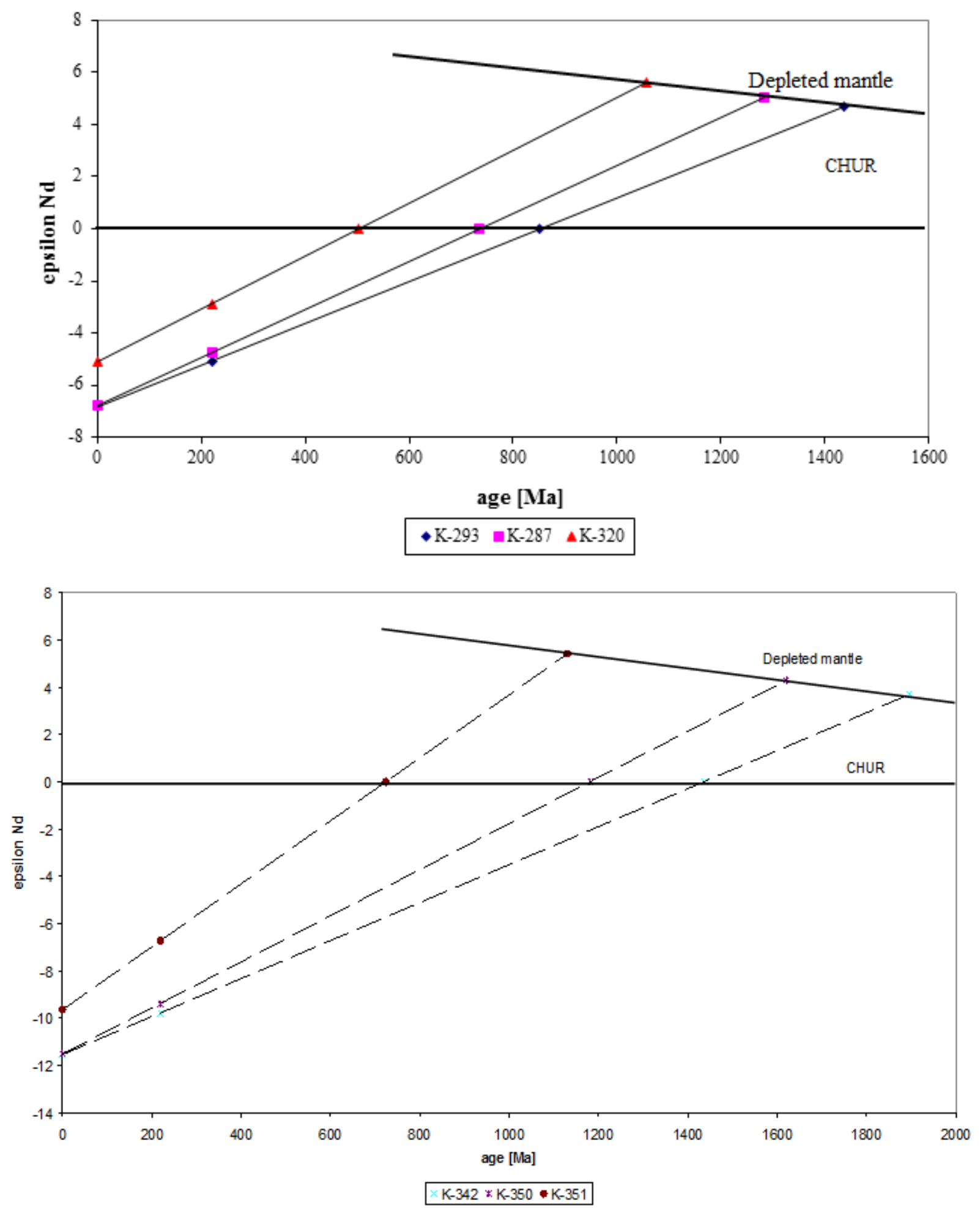

Fig. 6(a,b). Diagram of $\mathcal{E}_{N d} V$ s. Age of Sm-Nd from (a) Pia Ma massif 's nepheline Syenite and (b) Bang Phuc massif's Ijolite.

\subsection{Origin of Sodium alkaline Igneous Rocks in NE} Vietnam

In calculation on diagram of $\mathrm{Ne}-\mathrm{Ks}-\mathrm{Q}$ (MacKenzie,
1975) show that nephelin syenite in Pia Ma and Bang Phuc crystallized with condition of $\mathrm{T}=750-1000^{\circ} \mathrm{C}$ and $\mathrm{P}=1 \div$ $5 \mathrm{kbar}$. 

Evidence of Paleohotspot \& Mesohotspot Traces

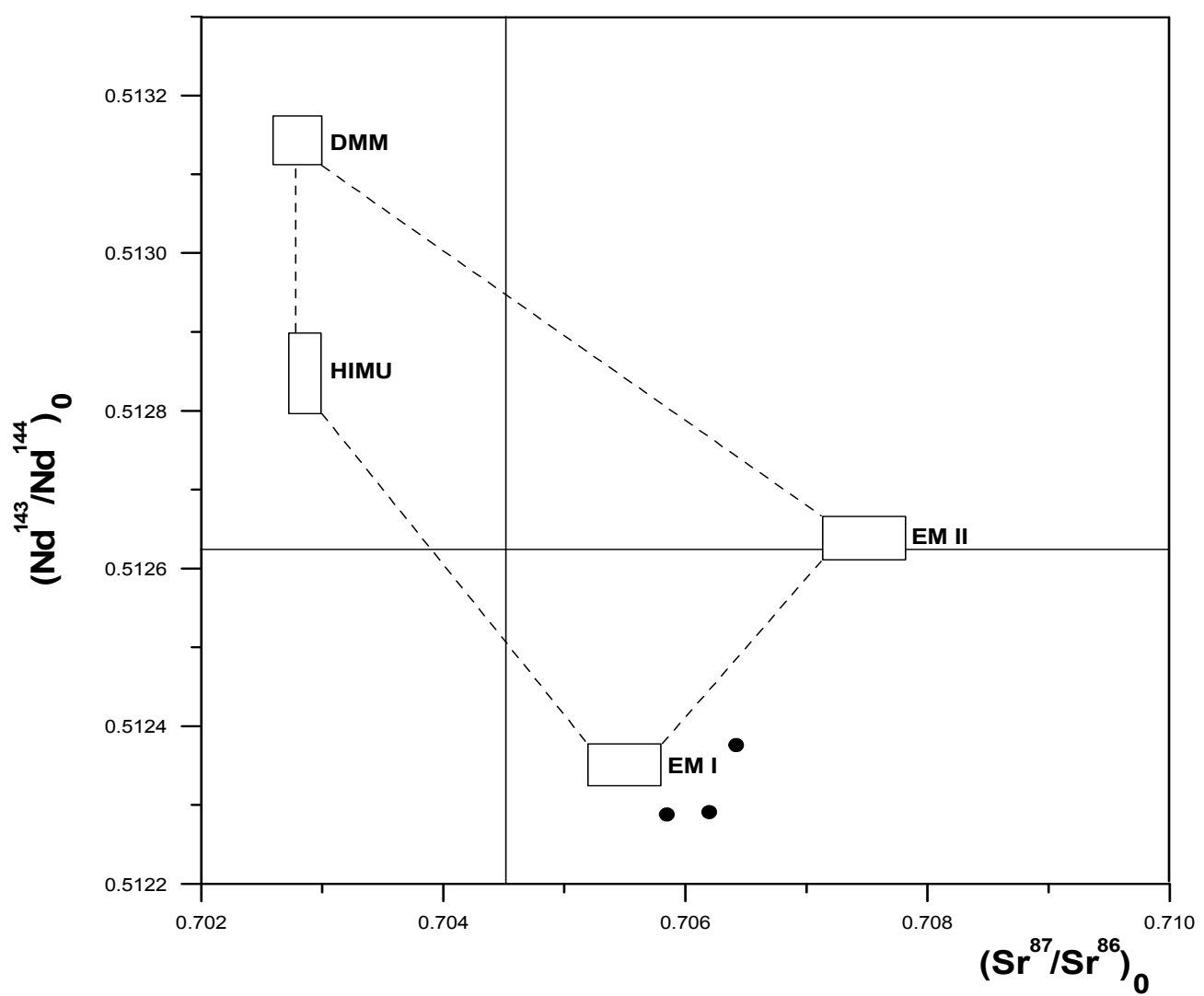

(a)

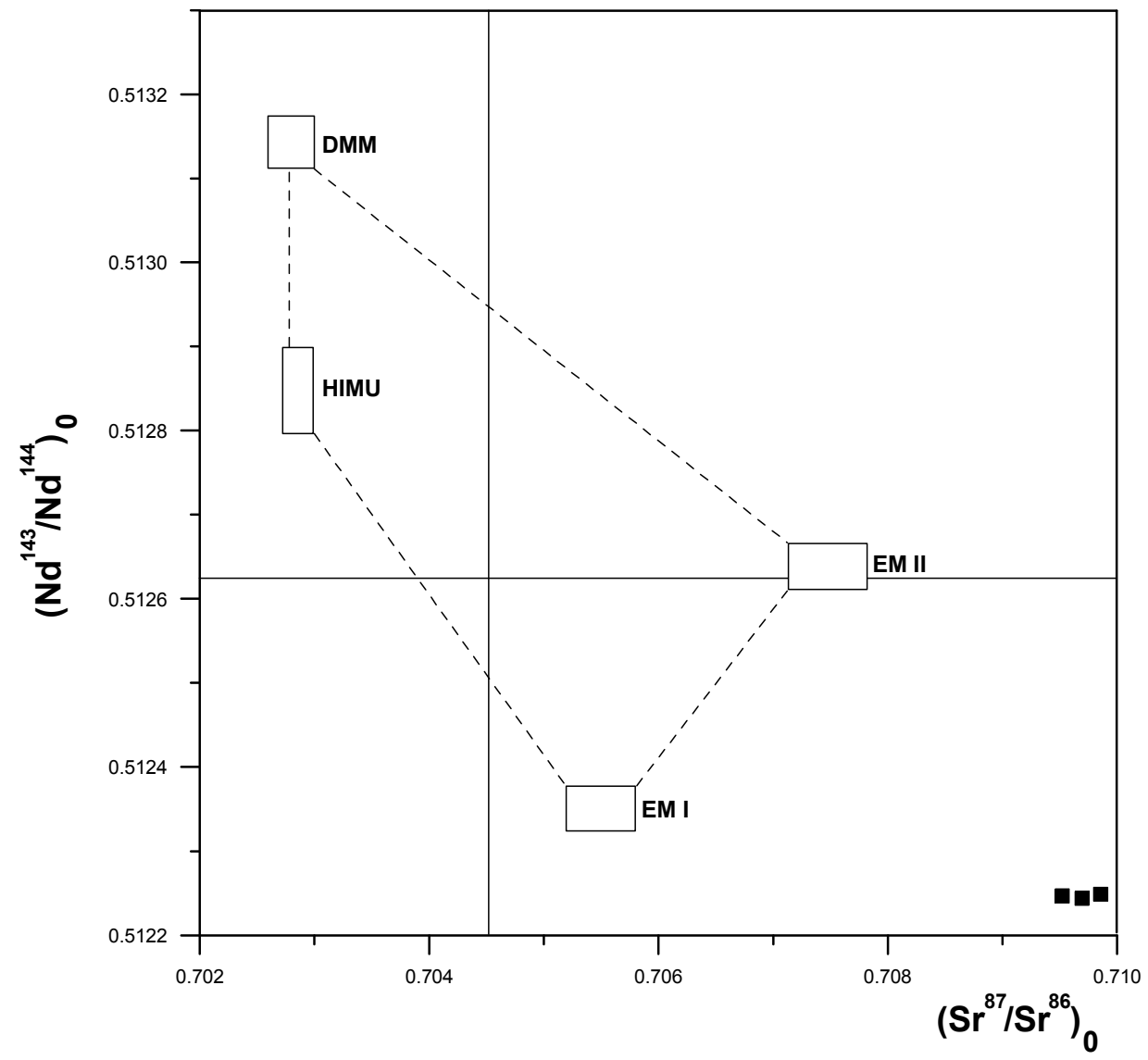

(b)

Fig. 7(a,b). Diagram of Sr-Nd Isotopic Ratios (after Faure G., 2001) for Sodium alkaline Igneous of Pia Ma Massif (a) and Bang Phuc Massif (b). 
Base on characteristics of Geology,petrography, minerals and geochemistry, especially trace and isotope elements demonstrated that alkaline ultramafic- mafic rocks and alkali syenitoid of Bang Phuc massif fractional crystallized from a melting liquid with composition of Al-high alkalic basalt its derived by partial melting of enriched mantle $\mathrm{EM}_{1}(<5 \%)$ and contaminated (high ratio of $\mathrm{Rb}-\mathrm{Sr}$ in moment $220 \mathrm{Ma}$ is ${ }^{87} \mathrm{Sr} /{ }^{86} \mathrm{Sr}_{(220)}=0,709893 \div 0,713856$ and low ratio of $\mathrm{Sm}-$ $\mathrm{Nd}-{ }^{143} \mathrm{Nd} /{ }^{144} \mathrm{Nd}{ }_{(220)}=0,511854 \div 0,512010$ with $\varepsilon_{\mathrm{Nd}(220)}=-$ $9,79 \div-6,73)$, crystallized age about $220 \div 231 \pm 23 \mathrm{Ma}$, according to Late Triassic period $\left(\mathrm{T}_{3} \mathrm{r}\right)$. Resemble one another on geochemical index and different on ratios of immobile elements between Bang Phuc and Pia Ma massifs show that sodium alkaline igneous formation in NE Vietnam have the same magmatic origin but different on time of occurrence in processe of magmatism.

\section{Conclusion}

Appearance of sodium alkaline igneous formations have mantle origin above like proved during Early Paleozoi and Early Mesozoi in Viet Bac Craton shown that in region, activities of interplate magmas may be relative to temperature anomalies or hotspot inner mantle lawfully. Space of time from Early PZ to Early MZ about $220 \div 250$ $\mathrm{Ma}$, and distance between positions where appearance alkaline magmatic formations indicator to tracks hot spot ( from Pia Ma to Cho Don - Ngoi Biec) about $150 \div 250 \mathrm{~km}$. Thus, able to calculated that from Early Cambrian to Late Trassic, Viet Bac continental lithosphere belong to South Chinese terrance splited from Gondwana and move toward North (I. Metcalfe, 1996) with speed about $0,7 \div 2,2 \mathrm{~mm} /$ year

Appearance of alkaline basalt and basanite formations with age of Neogene in coast of Vietnam Centre and East Sea show that possibly, this hotspots reactivated in Eocen and by the way to opened the East Sea.

\section{References}

[1] Chi N.T et al., 2004. Petrology and Metallogeny of alkaline magmatic formations in North Vietnam. Concluded report of Project, Documented in Institute of Geological InformationArchives and Museum. Hanoi (558p.)

[2] Condie K.C., 1989. Plate tectonic and Crust Evolution (Third edition). Pergarmon Press, New York.

[3] Deer W. A., Howie R. A. and Zussman J. 1992: An introdution to the rock - forming minerals. Longman scientific \& technical.

[4] Edgar A.E., 1987. The genegis of alkaline rocks magmas with emphasis on their sources regions: Inference from experimental studies. In : Fitton and Upton. 29-52

[5] Faure G., 1986. Principles op Isotope Geology (Second edition).Wiley, New York. 589 p.

[6] Faure G., 2001. Origin of Igneous Rocks- The isotopic Evidence. Springer. $496 \mathrm{P}$.

[7] Henderson P. (ed).,1984. Rare Earth Element Geochemistry, Developments in Geochemistry 2. Elservier. New York. 150 p.

[8] Le Bas M.J.,et al., 1987. Nephelinites and carbonatites. In : Alkaline Rocks. Fitton J.G. and Upton B.G.J., (eds)., Geol, Soc. Spe, Publ. 30.

[9] MacKenzie,D.P., and Weiss,N., 1975.Speculation on the thermal and tectonic history of the Earth.Geophys. J.Roy. Astro. Soc., 42, 131-174

[10] Metcalfe, I. 1996. IGCP Lecture: Gondwana dispersion \& Asian accretion. The Australian Geologist, No. 98, pp. 23-29.

[11] Sorensen, H. (ed),. 1979. Alkaline Rocks. Wiley, New York. $622 p$

[12] Wilson,J.T.,1963. A Possible origin of the Hawaiian islands. Can.J. Phys. 41, 863-870 